\title{
PENGEMBANGAN SOAL STATISTIKA UNTUK MENINGKATKAN KEMAMPUAN KONEKSI MATEMATIS SISWA
}

\author{
Azzahro Nurul Furqoni', Yuriska Destania ${ }^{2}$ \\ 1Program Studi Pendidikan Matematika, Universitas Muhammadiyah Bengkulu \\ 2Universitas Muhammadiyah Bengkulu, Indonesia \\ azzahronurfurqoni@gmail.com
}

\begin{abstract}
:
This research aims to produce a product in the form of problem-connections of students mathematical was valid and practical (legible). This method of research was research and development. The research was conducted in Bengkulu City with the research subject of 6 students of grade VIII junior high school students and was carried out in May-June 2020. The method of data collection in development was carried out using Tessmer's, which consists of preliminary, selfevaluation, expert review, and one-to-one. In the preliminary, two stages must be passed, namely preparation from completion. Was analyzing the curriculum, students, and material. Then, the completing the results of the students, curriculum evaluation, and the material was used as a reference for designing the mathematical connection ability, from the solution it produces 20 prototypes which are then assessed and fixed on self-evaluation. Of the 20 prototypes, these items will go through the validation stage (expert review) after 3 validation. Then, obtained 14 valid prototype items based on quantitative and qualitative analysis and test on 6 students to see the practicality or readability of items (one-to-one). The one-to-one stage was carried out to get comments on each question item to be analyzed qualitatively and quantitatively. Based on the qualitative comments, most of the provided students already understand the problem (legible) according to data, the average preceding data (legible) was recorded in the description of the preemptive questions at intervals of $4 \leq R P_{\text {produc }} \leq 5$.
\end{abstract}

Keywords: Questions development, Mathematical connections, Statistics material.

\section{PENDAHULUAN}

Kemendikbud (2013) menjelaskan bahwa mata pelajaran matematika untuk Sekolah Menengah Pertama bertujuan agar siswa memiliki kompetensi sikap logis, kritis, analisis, kreatif, cermat, teliti, bertanggung jawab, reponsif, dan tidak menyerah dalam memecahkan masalah. Menurut Permendikbud (2014) salah satu tujuan pembelajaran matematika dalam kurikulum 2013 tujuan pelajaran matematika agar siswa memahami konsep matematika, menjelaskan keterkaitan antarkonsep dan mengaplikasikan konsep atau algoritma secara luwes, akurasi, efesien, dan tepat dalam pemecahan masalah. Menjelaskan keterkaitan antarkonsep merupakan aspek matematika yang perlu dikembangkan pada koneksi matematis siswa.

Koneksi matematis merupakan salah satu aspek kemampuan matematika yang harus dicapai melalui kegiatan pembelajaran. National Council of Teachers of Mathematics (Anggraena, 2019) menyimpulkan dalam pelaksanaan pembelajaran matematika, guru harus memperhatikan lima kemampuan matematis, yaitu: koneksi (connections), penalaran (reasoning), komunikasi (communications), 
pemecahan masalah (problem solving), dan representasi (representations). Konsep dan prinsip dalam matematika berkaitan satu dengan lainnya, sehingga salah satu fokus utama tujuan pembelajaran matematika dalam Permendikbud dan NCTM adalah kemampuan koneksi matematis.

Kemampuan koneksi matematis merupakan kemampuan siswa untuk mengaitkan pengalaman dalam kehidupan sehari-hari, materi lain, dan disiplin ilmu lain. Menurut NCTM (Anggraena, 2019) menjabarkan indikator kemampuan koneksi matematis yaitu, (1) koneksi antar topik matematika, (2) koneksi dengan disiplin ilmu diluar matematika, dan (3) koneksi dengan kehidupan sehari-hari. Kemampuan koneksi matematis membantu siswa memahami bagaimana ide-ide matematika yang berbeda saling berkaitan.

Keterkaitan tersebut berhubungan dengan pendidikan abad 21 yaitu kemampuan yang harus dikuasai oleh setiap siswa. Kemampuan tersebut terbagi menjadi 4 bagian, yaitu (1) kemampuan berpikir kritis (critical thinking), (2) kemampuan kreativitas (creativity), (3) kemampuan komunikasi (communication), (4) kemampuan kolaborasi (collaboration) (Munawwarah, Laili, \& Tohir, 2020). Salah satu kemampuan tersebut yaitu komunikasi memiliki keterkaitan dengan kemampuan koneksi matematis. Menurut Hodiyanto (2017), komunikasi adalah kemampuan siswa menyampaikan ide baik secara lisan maupun tulisan. Dalam menyampaikan ide tersebut dibutuhkan kemampuan koneksi matematis. Jika tidak ada kemampuan koneksi matematis maka komunikasi tidak tersampaikan secara menyeluruh. Salah satu tujuan untuk menyampaikan komunikasi tersebut yaitu melatih siswa dengan memberikan soal-soal berkemampuan koneksi matematis.

Hasil penelitian oleh Nopriyanti (2015) menghasilkan suatu produk pengembangan soal matematika yang dapat digunakan untuk mengukur kemampuan koneksi matematis siswa SMP. Berdasarkan hasil penelitian, maka dapat disimpulkan prototype perangkat soal yang dihasilkan adalah sebanyak 20 soal dikategorikan valid dan praktis baik secara kualitatif maupun secara kuantitatif, dimana hampir semua validator menyatakan baik berdasarkan konten (sesuai dengan indikator kemampuan koneksi matematis), konstruk (mengukur kemampuan koneksi matematis, kaya dengan konsep, sesuai dengan level siswa kelas IX SMP), dan bahasa (sesuai dengan EYD, soal tidak bebelit-belit, soal tidak mengandung penafsiran ganda, batasan pertanyaan dan jawaban jelas). Adapun valid secara kuantitatif tergambar berdasarkan analisis butir soal (validasi butir soal), sedangkan praktis tergambar dari hasil ujicoba, dimana semua siswa dapat menggunakan perangkat soal dengan baik.

Menurut Arikunto (2008) menyatakan bahwa seorang guru dituntut untuk mampu merancang penilaian dari hasil pebalajaran yang dilaksanakan, sehingga dapat mengetahui sejauh mana keberhasilan desain dan ketercapaian pelaksanaan pembelajaran yang dibuat mengacu pada tujuan kegiatan belajar mengajar. Kenyataannya, berdasarkan hasil wawancara dengan salah satu guru matematika di SMP Negeri 11 Kota Bengkulu, guru hanya memberikan koneksi pada awal proses pembelajaran dan koneksi yang masih terbatas dengan yang ada di buku serta guru memiliki keterbatasan dalam mengembangkan soal yang disebabkan keterbatasan sumber yang ada.

Berikut contoh soal yang didapatkan dari Buku Guru (As'ari, Tohir, Valentino, Imron, \& Taufiq, 2017) dan Buku paket siswa Matematika edisi revisi 2017 kelas

Alifmatika: Jurnal Pendidikan dan Pembelajaran Matematika, Desember 2020, Vol. 2, No. 2 
VIII semester 2 (As'ari, Tohir, Valentino, Imron, Taufiq, et al., 2017) yang digunakan dalam proses pembelajaran di sekolah.

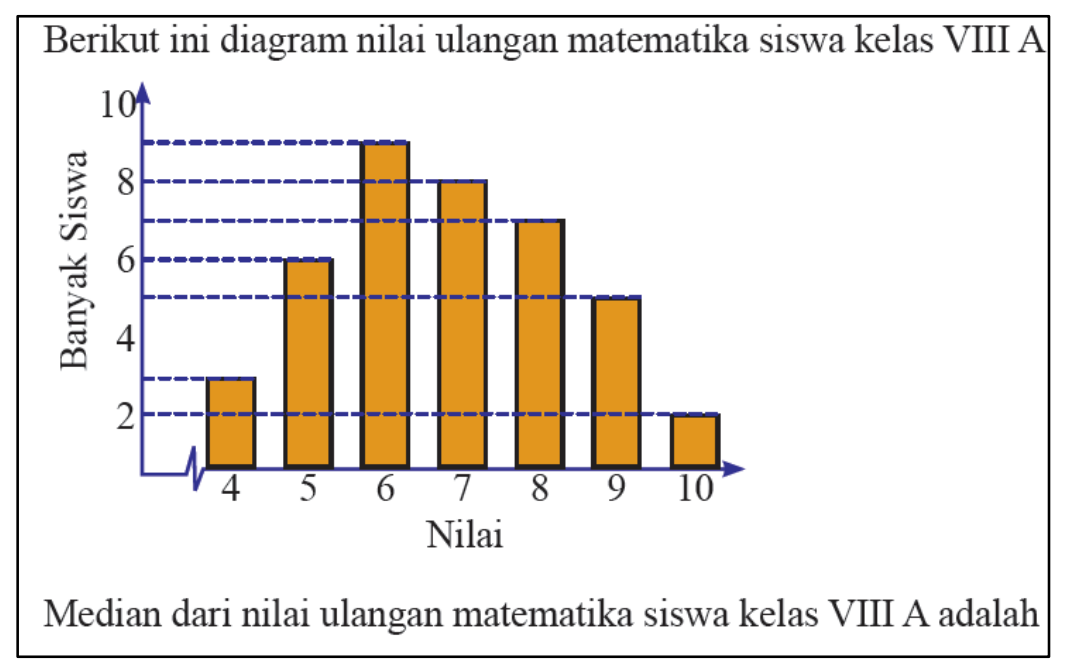

Gambar 1. Soal latihan yang ditemukan di dalam buku

Berdasarkan Gambar 1 di atas dapat dilihat bahwa soal-soal yang telah ada didalam buku pelajaran dengan materi statistika sudah ada, tetapi masih kurang pada indikator koneksi disiplin ilmu lain dan koneksi materi lain. Untuk mengatasi permasalahan di atas, maka perlu dilakukan pengembangan soal yang betujuan untuk menambah sumber untuk guru dengan materi statistika.

Menurut Ulpah (2009) Statistika merupakan salah satu cabang ilmu dari matematika yang mempelajari tentang pengumpulan data, pengelolaan data, penganalisisan data, serta penarikan kesimpulan berdasarkan hasil analisis data. Statistika juga merupakan ilmu pengetahuan yang sangat penting untuk dipelajari oleh siswa dan merupakan salah satu materi (standar isi) yaitu statistika dipelajari di kelas VIII SMP/MTs pada kurikulum 2013 di semester genap (As'ari, Tohir, Valentino, Imron, Taufiq, et al., 2017).

Materi Statistika digunakan untuk melatih kemampuan koneksi matematis siswa, dengan menambah pengalaman terhadap soal-soal yang berkaitan dikehidupan sehari-hari saat ini. Melalui materi statistika kemampuan koneksi matematis siswa terbentuk melalui pengalaman dari proses pembelajaran yang menduga dan mengembangkan pikiran siswa menggunakan wawasan didalam suatu konteks tertentu untuk menguji kemajuan dalam konteks lain.

Salah satu cara untuk mengembangkan kemampuan koneksi matematis tersebut dengan memberikan siswa latihan berupa soal essay. Menurut Arikunto (2018) salah satu kelebihan soal essay adalah "memberikan kesempatan kepada siswa untuk mengutarakan maksud dengan gaya bahasa dan cara sendiri". Berdasarkan uraian di atas, maka dilakukan penelitian tentang pengembangan soal essay untuk kemampuan koneksi matematis siswa kelas VIII pada materi Statistika. Hasil soal yang telah dikembangkan diharapkan dapat digunakan guru untuk menambah sumber soal latihan untuk kemampuan koneksi matematis dalam pembelajaran matematika.

Alifmatika: Jurnal Pendidikan dan Pembelajaran Matematika, Desember 2020, Vol. 2, No. 2 


\section{METODE PENELITIAN}

Jenis penelitian ini adalah penelitian pengembangan (development research). Penelitian pengembangan ini bertujuan untuk menghasilkan produk berupa soalsoal kemampuan koneksi matematis siswa. Penelitian pengembangan ini menggunakan metode yang mengikuti model pengembangan formative evaluation yang diacu dari Tessmer 1993 (Zulkardi, 2006). Model pengembangan Tessmer terdiri dari preliminary, self evaluation, expert review, dan one-to-one. Pada tahap self evaluation, expert review dan one-to-one dihasilkan prototype. Bentuk diagram alir dari penelitian pengembangan ini adalah sebagai berikut.

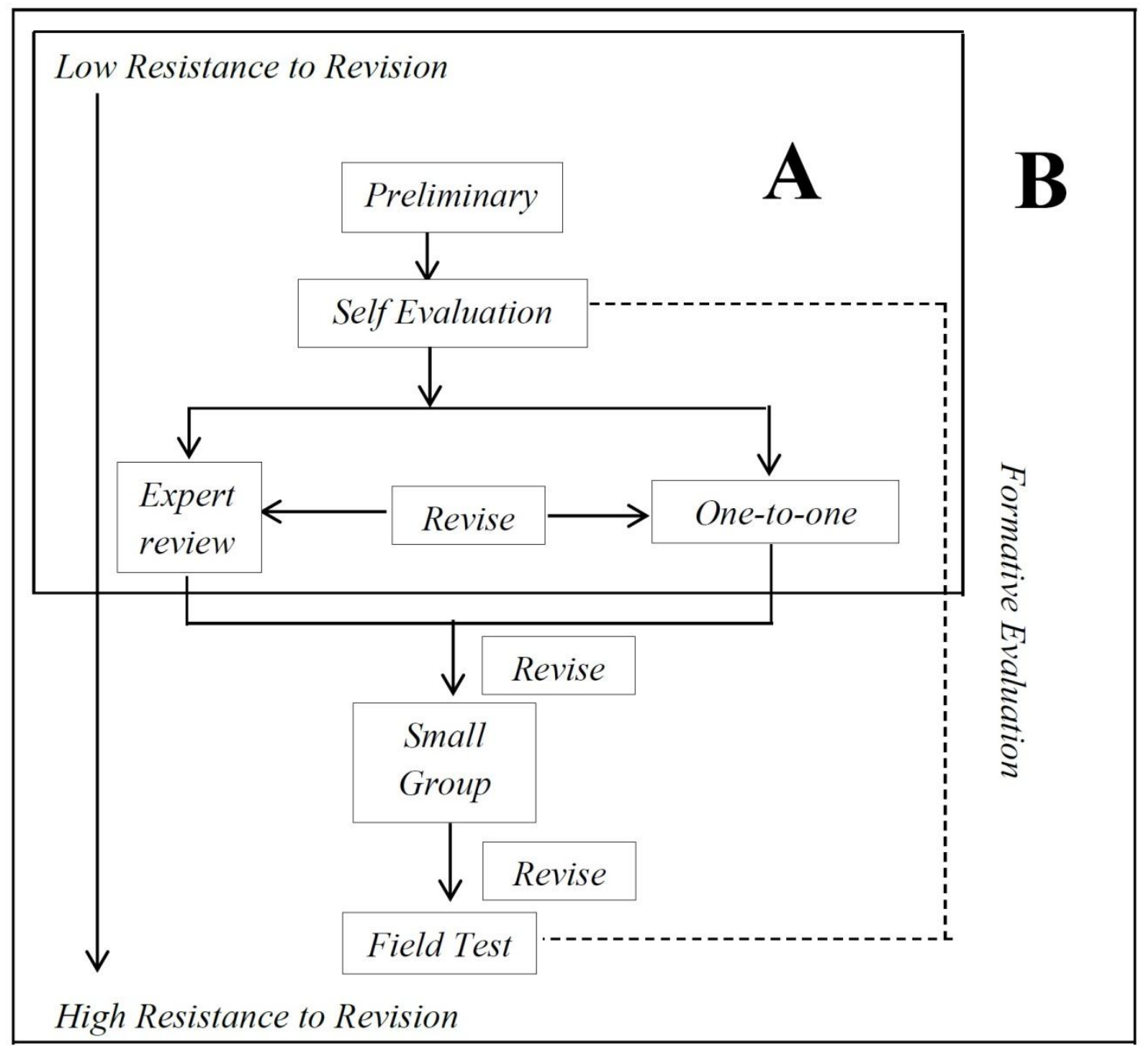

Gambar 2. Alur Desain Tessmer 1993 (Zulkardi, 2006)

Adapun pada penelitian ini langkah Tessmer hanya sampai A. Pada tahap Preliminary, self evaluation, expert review dan one-to-one menghasilkan soal yang valid dan praktis. Ada dua tahap yang dilalui dalam Alur Desain Tessmer 1993 yaitu tahap awal (preliminary) dan tahap formative evaluation, yang meliputi (1) self evaluation, (2) prototyping (expert review, one-to-one dan small group) dan (3) field test.

Alifmatika: Jurnal Pendidikan dan Pembelajaran Matematika, Desember 2020, Vol. 2, No. 2 
Pada tahap preliminary ada dua tahap yang harus dilalui yaitu tahap persiapan dan tahap pendesaian. Pada tahap persiapan, yang harus dilakukan adalah menentukan tempat dan objek penelitian, mengobservasi, melakukan analisis kurikulum, materi, dan siswa. Selanjutnya, melakukan tahap pendesaian dengan mendesaian kisi-kisi dan soal kemampuan koneksi matematis, kemudian dilanjutkan ke tahap formative evaluation.

Tahap formative evaluation yang pertama dilakukan adalah self evaluation, dimana desaian yang telah dibuat dinilai dan diperbaiki sendiri oleh peneliti dengan memperhatikan penulisan dan bahasa sebelum diberikan kepada pakar atau validator. Hasil tahap self evaluation disebut prototype I. Kemudian, prototyping (expert review, one-to-one dan small group), tahap expert review merupakan tahap validasi yang dilakukan oleh pakar (expert). Para pakar menelaah konten produk (soal) dengan memperhatikan konstruksi, materi, dan bahasa dari masing-masing butir soal (prototype), tanggapan dan saran dari validator digunakan untuk merevisi produk. Saran-saran tersebut ditulis pada lembar validasi, secara bersamaan dilakukan tahap one-to-one.

Pada tahap one-to-one, prototype I diujicobakan kepada 6 orang siswa digunakan untuk uji keterbacaan soal dengan memberikan komentar dan mengisi lembaran angket terhadap soal. Hasil dari komentar siswa bertujuan sebagai pertimbangan keterbacaan soal yang telah dibuat. Hasil yang diperoleh dari expert review dan one-to-one akan menjadi pertimbangan dalam merevisi prototype $\mathrm{I}$. Setelah merevisi prototype I akan menghasilkan prototype II. Prototype II akan diujicobakan pada tahap small group, tetapi tahap ini tidak dilakukan dikarenakan keterbatasan situasi pandemi (COVID-19) dan siswa yang digunakan pada tahap one-to-one adalah siswa kelas VIII SMP yang berada di lingkugan sekitar peneliti.

Instrumen pengumpulan data yang digunakan dalam penelitian adalah dokumen, wawancara lembar validasi, dan lembar angket respon siswa. Dokumen yang berisi data-data tentang kurikulum, materi dan soal-soal kemampuan koneksi matematis. Wawancara dilakukan pada tahap one-to-one, siswa menanggapi keterbacaan dari soal yang telah diberikan. Lembar validasi digunakan untuk penilaian dan informasi sebagai saran dan komentar dari pakar tentang soal yang dihasilkan. Lembar validasi berupa penilaian dari pakar untuk soal divalidasi yang berisi konten produk (konstruksi, materi dan bahasa). Lembar angket respon siswa digunakan untuk memperoleh data kepraktisan atau keterbacaan soal yang akan ditujukan kepada siswa. Lembar angket respon siswa sebelumnya telah divalidasi pada tahap expert review, didalam angket tersebut berisi apakah soal telah memenuhi kriteria. Hasil dari respon siswa akan dijadikan bahan untuk mengetahui kepraktisan soal. Instrumen ini digunakan pada tahap one-to-one untuk mendapatkan data dari repon siswa.

Teknik analisis data yang digunakan pada penelitian ini adalah analisis kualitatif yaitu validitas dan praktis, dimana validitas harus memenuhi materi, konstruk dan bahasa.

1. Validitas

Teknik analisis data validitas, dimana tahap expert review menghasilkan prototype. Komentar dan saran validator pada tahap tersebut dianalisis secara kualitatif yang digunakan untuk merevisi prototype. Prototype direvisi berdasarkan

Alifmatika: Jurnal Pendidikan dan Pembelajaran Matematika, Desember 2020, Vol. 2, No. 2 
dari berbagai coretan, komentar atau kalimat-kalimat yang belum benar dan tepat. Tujuan merevisi prototype adalah untuk memperoleh soal yang memadai dan valid untuk diujicobakan.

Kriteria pertimbangan validasi soal adalah rekapitulasi lembar validasi hasil pertimbangan pada setiap validator. Validator memberikan nilai 1 (ya) untuk menilai bahwa soal telah valid dan 0 (tidak) untuk tidak valid, serta memberikan komentar/ saran pada kolom yang disediakan atau langsung pada naskah soal. Adapun kriteria penilaian validator berdasarkan materi, konstruksi dan bahasa.

Setelah soal-soal yang dikembangkan ini dilakukan validasi berdasarkan materi, konstruksi dan bahasa, validator memberikan kesimpulan apakah butir soal sudah valid atau tidak valid. Penilaian dari beberapa validator yang berbedabeda yaitu valid atau tidak valid terhadap soal essay kemampuan koneksi matematis siswa kelas VIII pada materi statistika akan dianalisis menggunakan uji $Q$ Cochran Test untuk mencari keseragaman validator tentang kevalidan butir soal. Adapun langkah pada uji $Q$ Cochran sebagai berikut.

a) Hipotesis yang diuji

Ho : Semua validator seragam menyatakan semua soal telah valid

$\mathrm{Ha}:$ Semua validator tidak seragam menyatakan semua soal telah valid

b) Mencari $Q$ hitung dengan menggunakan rumus sebagai berikut.

$$
Q=\frac{(k-1)\left[k \sum_{j=1}^{k} G_{j}^{2}-\left(\sum_{j=1}^{k} G_{j}\right)^{2}\right]}{k \sum_{i=1}^{k} L_{i}-\sum_{i=1}^{k} L_{i}^{2}}
$$

(Sugiyono, 2012)

Keterangan:

$Q: Q$ hitung

$k:$ jumlah validator

$G_{j}$ : jumlah yang sukses (jumlah yang mendapat nilai 1)

$L_{i}$ : jumlah yang sukses semua validator

$L_{i}^{2}:$ kuadrat dari $L_{i}$

Distribusi sampling $Q$ mendekati distribusi Chi kuadrat ( $Q$ tabel). Oleh karena itu, untuk menguji signifikasi harga $Q$ hitung, maka perlu dibandingkan dengan hargaharga kritis Chi kuadrat ( $Q$ tabel).

c) Penentuan $Q$ tabel

Dengan derajat kebebasan yang digunakan untuk mencari $Q$ ttabel adalah $d k=$ $k-1$, kemudian samakan dengan tabel nilai-nilai chi kuadrat. Dalam penelitian ini taraf signifikansi yaitu 5\%.

d) Keputusan

Setelah melalui langkah-langkah di atas akan ditarik suatu kesimpulan. "Tolak $\mathrm{H}_{0}$ dan terima $\mathrm{H}_{\mathrm{a}}$, jika $Q$ hitung $\geq Q$ tabel, dan terima $\mathrm{H}_{0}$ dan tolak $\mathrm{H}_{\mathrm{a}}$, jika $Q$ hitung $<Q$ tabel" (Sugiyono, 2012).

e) Kesimpulan

1) Jika tolak $\mathrm{H}_{0}$, artinya proporsi butir soal valid oleh validator berbeda-beda pada semua soal. Artinya belum ada kesepakatan diantara para validator tentang kevalidan butir soal. Jika hal ini terjadi, maka perlu dilakukan revisi terhadap butir soal yang belum valid. 
2) Jika terima $\mathrm{H}_{0}$, artinya proporsi jawaban valid pada setiap butir soal dianggap sama. Dengan demikian, semua validator dianggap sepakat mengenai kevalidan setiap butir soal.

Pada $Q$ hitung dilakukan berlanjutan sampai diperoleh nilai $Q$ hitung $<Q$ tabel.

\section{Kepraktisan}

Setelah valid berdasarkan expert review, kemudian diujicobakan pada one-toone untuk memastikan bahwa soal-soal tersebut "terbaca" oleh siswa dengan memberikan lembar penilaian respon/ lembar keterbacaan untuk mengukur keterbacaan siswa terhadap soal dengan cara menghitung nilai rata-rata hasil pengisian lembar keterbacaan soal. Kepraktisan memenuhi keterbacaan dari setiap butir soal, untuk mengetahui nilai keperaktisan soal dapat dilihat dari respon siswa saat membaca soal. Kepraktisan penggunaan produk dilihat dari tahap ujicoba, uji kepraktisan ini ditentukan dengan cara skor rata-rata kepraktisan siswa ke-I dibagi banyak siswa, skor rata-rata diambil dari hasil pengisian lembar kepraktisan penggunaan produk, nilai rata-rata hasil pengisian lembar kepraktisan produk tersebut dapat dicari dengan rumus sebagai berikut.

$$
R P_{\text {produk }}=\frac{\sum_{i=1}^{n} P_{i}}{n}
$$

Keterangan:

$R P_{\text {produk }} \quad$ : rata-rata kepraktisan produk

$\sum_{i=1}^{n} P_{i} \quad$ : jumlah skor penilaian ke- $i$

$n \quad$ : banyak aspek yang dinilai

Setelah dihitung rata-rata hasil penilaian lembar kepraktisan penggunaan soal, maka tingkat kepraktisan soal yang dihasilkan dapat ditentukan berdasarkan tingkat kategori pada tabel kriteria penskoran kepraktisan yaitu sebagai berikut.

Tabel 1. Kriteria Penskoran Kepraktisan

\begin{tabular}{cc}
\hline Interval Skor & Kategori Kevalidan \\
\hline $4 \leq R P_{\text {produk }} \leq 5$ & Sangat Praktis \\
$3 \leq R P_{\text {produk }}<4$ & Praktis \\
$2 \leq R P_{\text {produk }}<3$ & Kurang Praktis \\
$1 \leq R P_{\text {produk }}<2$ & Tidak Praktis \\
\hline Tabel diadopsi dari Khabibah (Riwayati \& Ridzky, 2020)
\end{tabular}

Soal yang dikembangkan dikatakan praktis jika interval skor rata-rata hasil pengisian lembar kepraktisan/ keterbacaan soal minimalisasi berada pada interval kategori praktis yaitu $3 \leq R P_{\text {produk }}<4$.

Alifmatika: Jurnal Pendidikan dan Pembelajaran Matematika, Desember 2020, Vol. 2, No. 2 


\section{HASIL DAN PEMBAHASAN}

Ada tiga tahap pada penelitian ini, yaitu preliminary, self evaluation, expert review dan one-to-one. Kegiatan yang dilakukan dalam penelitian pengembangan soal ini adalah sebagai berikut.

1. Preliminary

a. Persiapan

Pada tahap ini, dilakukan beberapa analisis yaitu sebagai berikut.

1) Analisis Kurikulum

Menurut NCTM (2000) menyatakan bahwa koneksi matematis terjadi karena matematika tidak terpisah dalam berbagai topik yang lain, matematika merupakan satu kesatuan. Matematika juga tidak bisa dipisahkan dari ilmu selain matematika dan masalah-masalah yang terjadi dalam kehidupan. Tanpa koneksi matematis maka siswa harus belajar dan mengingat terlalu banyak konsep dan prosedur matematika yang saling terpisah.

Adapun untuk menganalisis kurikulum tidak semua materi bisa digunakan dalam kemampuan koneksi matematis, maka dalam menganalisis kurikulum harus menyamakan indikator kemampuan koneksi matematis dengan materi Statistika. NCTM (2000) menjabarkan indikator kemampuan koneksi matematis, yaitu: (1) koneksi antar topik matematika, (2) koneksi dengan disiplin ilmu diluar matematika, dan (3) koneksi dengan dunianyata atau kehidupan sehari-hari.

Materi yang digunakan adalah materi yang paling banyak berhubungan dengan dunia nyata. Keterkaitan materi Statistika dengan pokok bahasan lain atau materi lain yaitu terkait dengan materi: bilangan, persentase, perbandingan, aritmatika sosial, dan persamaan serta pertidaksamaan linier satu variabel. Keterkaitan materi statistika dengan disiplin ilmu lain seperti menghitung ratarata suhu (dalam fisika) dan menentukan jangkauan interkuartil panjang perrtumbuhan kecambah (dalam biologi). Keterkaitan dengan kehidupan seharihari, seperti: menghitung rata-rata pertambahan pasien covid-19, menentukan rata-rata penjualan, menentukan median dan modus ukuran sepatu dalam satu kelas, dan sebagainya. Terlihat secara analisis bahwa statistika bisa memenuhi indikator kemampuan koneksi matematis.

2) Analisis Materi

Tujuan analisis materi adalah untuk mengidentifikasi bagian-bagian utama yang akan dipelajari pada materi pokok yaitu statistika. Pada analisis ini dilakukan analisis alokasi waktu pembelajaran, dan konsep-konsep yang harus dikuasai siswa. Pada alokasi waktu pembelajaran, materi Statistika memiliki waktu pelajaran selama 10 jam pelajaran yang terdapat dalam silabus. Materi tersebut memiliki keterbatasan waktu, sehingga diperlukan banyak soal-soal yang dapat melatih kemampuan koneksi matematis siswa. Dalan materi tersebut terdapat banyak konsep yang harus dikuasai siswa seperti distribusi data, rata-rata suatu data, median dan modus suatu data, kuartil, jangkauan dan jangkauan interkuartil. Selain itu, materi pokok statistika ini bisa diaplikasikan dalam kehidupan seharihari.

3) Analisis Siswa

Analisis siswa bertujuan untuk mengetahui karakteristik siswa, sebagai acuan untuk merancang dan mengembangkan soal. Adapun hasil analisis siswa sebagai berikut.

Alifmatika: Jurnal Pendidikan dan Pembelajaran Matematika, Desember 2020, Vol. 2, No. 2 
a) Siswa yang digunakan rata-rata berusia 13-14 tahun.

b) Siswa belum terbiasa untuk belajar mandiri.

c) Dalam proses pembelajaran guru masih lebih aktif daripada siswa.

d) Dalam proses pembelajaran, koneksi matematis diberikan hanya sebatas apersepsi.

e) Siswa belum terbiasa menyelesaikan soal berkemampuan koneksi matematis.

b. Pendesaianan

Hasil dari analisis kurikulum, analisis materi, dan analisis siswa dijadikan acuan untuk mendesain soal kemampuan koneksi matematis. Langkah awal yang dilakukan pada tahap desain adalah menyusun kisi-kisi soal dengan melakukan analisis silabus. Analisis silabus bertujuan untuk mengetahui kompetensi inti (KI) dan kompetensi dasar (KD) dalam suatu materi.

\section{Self Evaluation}

Pada tahap ini, prototype yang telah didesain berdasarkan materi dan indikator yang berjumlah 20 soal dinilai dan diperbaiki sendiri berdasarkan materi, konstruksi, dan bahasa. Hal ini dilakukan sebelum proses expert review yang akan divalidasi oleh pakar.

\section{Expert Review}

Pada tahap ini prototype yang telah didesain divalidasi oleh tiga validator yaitu dosen Pendidikan Matematika Universitas Muhammadiyah Bengkulu dan satu orang guru SMP Negeri 11 Kota Bengkulu untuk memperoleh soal yang valid berdasarkan konten, yaitu: konstruksi, materi dan bahasa. Pada proses validasi pakar menelaah soal yang dianalisis secara kualitatif terhadap butir soal untuk validitas terutama content validity butir soal. Hasil telaah tersebut yang tertulis pada lembar soal sebagai komentar dan saran validator. Berikut ini adalah salah satu hasil expert review.

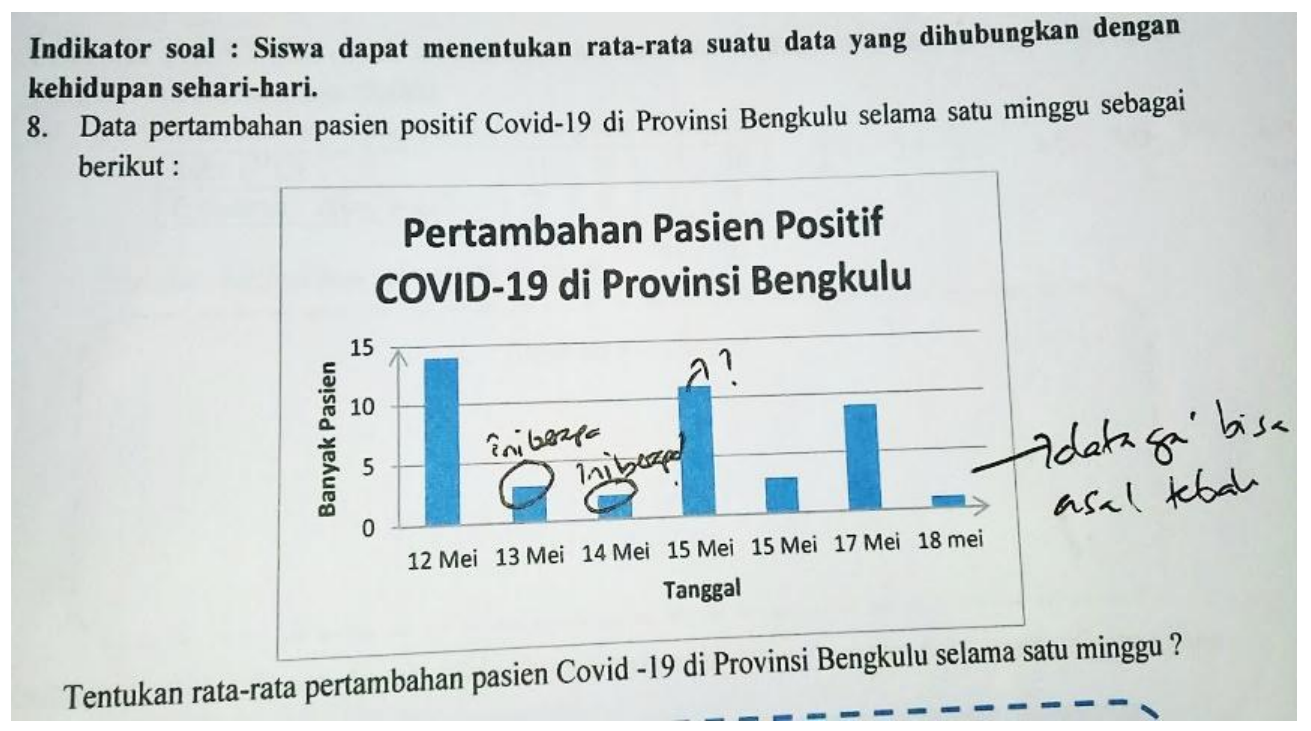

Gambar 3. Salah satu hasil expert review

Alifmatika: Jurnal Pendidikan dan Pembelajaran Matematika, Desember 2020, Vol. 2, No. 2 
Pada proses validasi ketiga prototype sudah dinyatakan valid oleh ketiga validator. Selanjutnya penilaian dari validator dilakukan analisis menggunakan $Q-$ Cochran untuk mencari keseragaman validator tentang kevalidan butir soal. Adapun hasil penilaian validator terhadap prototype I disajikan dalam Tabel 2 berikut.

Tabel 2. Penilaian Validator terhadap Butir Soal

\begin{tabular}{cccc}
\hline Nomor & \multicolumn{3}{c}{ Validator } \\
\cline { 2 - 4 } Soal & V1 & V2 & V3 \\
\hline 1 & 1 & 1 & 1 \\
2 & 1 & 1 & 1 \\
3 & 1 & 1 & 1 \\
4 & 1 & 1 & 1 \\
5 & 1 & 1 & 1 \\
6 & 1 & 1 & 1 \\
7 & 1 & 1 & 1 \\
8 & 1 & 1 & 1 \\
9 & 1 & 1 & 1 \\
10 & 1 & 1 & 1 \\
11 & 1 & 1 & 1 \\
12 & 1 & 1 & 1 \\
13 & 1 & 1 & 1 \\
14 & 1 & 1 & 1 \\
\hline
\end{tabular}

Keterangan: 1 = Valid, 0 = Tidak valid

Berdasarkan Tabel 2 di atas, terlihat bahwa validator 1, 2 dan validator 3 seragam, dikarenakan tidak ada satu butir soal yang berbeda.

\section{One-to-one}

Pada tahap ini soal diujicobakan kepada 6 siswa untuk mendapatkan komentar pada setiap butir soal. Berdasarkan komentar siswa, sebagian besar siswa sudah memahami soal (terbaca) sesuai dengan alur pikirannya. Berdasarkan respon siswa, didapatkan sejumlah data rata-rata kepraktisan (terbaca) dalam penggunaan soal dapat disajikan pada Tabel 3 berikut.

Alifmatika: Jurnal Pendidikan dan Pembelajaran Matematika, Desember 2020, Vol. 2, No. 2 
Tabel 3. Kriteria Praktis Soal

\begin{tabular}{c|c|c}
\hline Nomor Soal & Nilai & Kategori Kepraktisan \\
\hline 1 & 4,36 & Sangat Praktis \\
2 & 4,416 & Sangat Praktis \\
3 & 4,47 & Sangat Praktis \\
4 & 4,333 & Sangat Praktis \\
5 & 4,36 & Sangat Praktis \\
6 & 3,527 & Praktis \\
7 & 4,28 & Sangat Praktis \\
8 & 4,472 & Sangat Praktis \\
9 & 4,5 & Sangat Praktis \\
10 & 4,305 & Sangat Praktis \\
11 & 4,42 & Sangat Praktis \\
12 & 4,472 & Sangat Praktis \\
13 & 4,36 & Sangat Praktis \\
14 & 4,25 & Sangat Praktis \\
\hline
\end{tabular}

Berdasarkan hasil uji keterbacaan (one-to-one) pada Tabel 3 di atas, mendapat kesimpulan bahwa pengembangan soal dari nomor 1 sampai 14 ini dikategorikan sangat praktis, yaitu dengan nilai rata-rata berada pada interval $4 \leq$ $R P_{\text {produk }} \leq 5$. Penelitian pengembangan ini menghasilkan soal untuk kemampuan koneksi matematis siswa yang valid dan praktis.

Penelitian ini sejalan dengan penelitian dari Nopriyanti (2015) yaitu menghasilkan suatu produk pengembangan soal matematika yang dapat digunakan untuk mengukur kemampuan koneksi matematis siswa SMP. Berdasarkan hasil penelitian, maka dapat disimpulkan prototype perangkat soal yang dihasilkan adalah sebanyak 20 soal dikategorikan valid dan praktis baik secara kualitatif maupun secara kuantitatif, dimana hampir semua validator menyatakan baik berdasarkan konten (sesuai dengan indikator kemampuan koneksi matematis), konstruk (mengukur kemampuan koneksi matematis, kaya dengan konsep, sesuai dengan level siswa kelas IX SMP), dan bahasa (sesuai dengan EYD, soal tidak bebelit-belit, soal tidak mengandung penafsiran ganda, batasan pertanyaan dan jawaban jelas). Adapun valid secara kuantitatif tergambar berdasarkan analisis butir soal (validasi butir soal), sedangkan praktis tergambar dari hasil ujicoba, dimana semua siswa dapat menggunakan perangkat soal dengan baik. Dan sejalan dengan penelitian Lis (2017) yaitu soal-soal kemampuan koneksi matematis telah dinyatakan valid secara kualitatif oleh pakar, dan dari hasil analisis uji validitas butir soal diperoleh bahwa semua soal valid dengan $r=0,69$ yang berarti memiliki reabilitas tinggi.

Menurut Yusuf (2017) tes susunan pendidikan perlu dianalisis, dikaji ulang, direvisi, diuji coba dan disempurnakan lebih lanjut, dan perlu dilakukan analisis soal, sehingga dapat diketahui tingkat kesukaran dan daya pembeda soal. Penelitian ini hanya terbatas pada kriteria produk secara kualitatif yaitu kevalidan dan kepraktisan/ keterbacaan suatu produk. Pengembang soal yang baik harus memiliki kriteria produk yang baik dalam pengembangan soal yang terstandar

Alifmatika: Jurnal Pendidikan dan Pembelajaran Matematika, Desember 2020, Vol. 2, No. 2 


\section{Azzahro Nurul Furqoni \& Yuriska Destania}

baik secara kualitatif maupun secara kuantitatif. Berikut ini adalah produk soal essay untuk kemampuan koneksi matematis yang memenuhi kriteria secara kualitatif.

Tabel 4. Produk Soal Essay

\begin{tabular}{cl}
\hline $\begin{array}{c}\text { Butir } \\
\text { Soal }\end{array}$ & \multicolumn{2}{c}{ Soal } \\
\hline 1 & $\begin{array}{l}\text { Grafik berikut ini menunjukkan data penjualan hand sanitizer di } \\
\text { apotek Al-Fatih selama seminggu. }\end{array}$
\end{tabular}

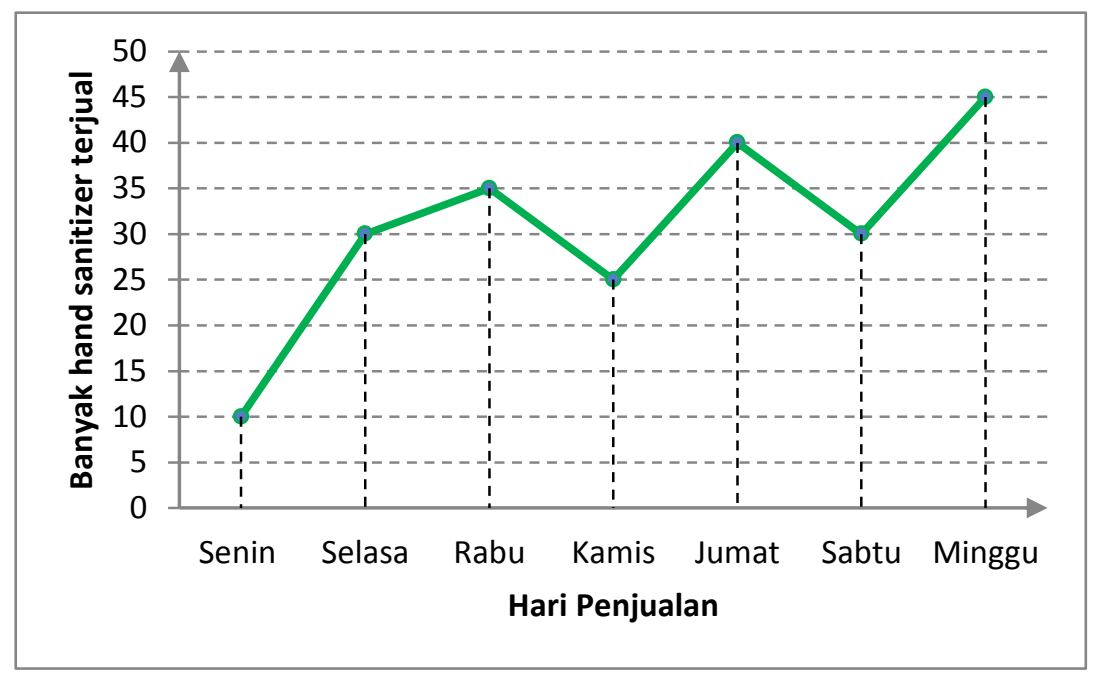

Pada hari apakah terjadi kenaikan penjualan hand sanitizer sebesar $50 \%$ ?

$2 \quad$ Diagram di samping menunjukkan data Data Penjualan penjualan Apotek Ceria. Jumlah penjualan obatobatan dan vitamin adalah 169 barang. Apakah penjualan hand sanitizer lebih banyak dari penjualan lainnya? Jelaskan?

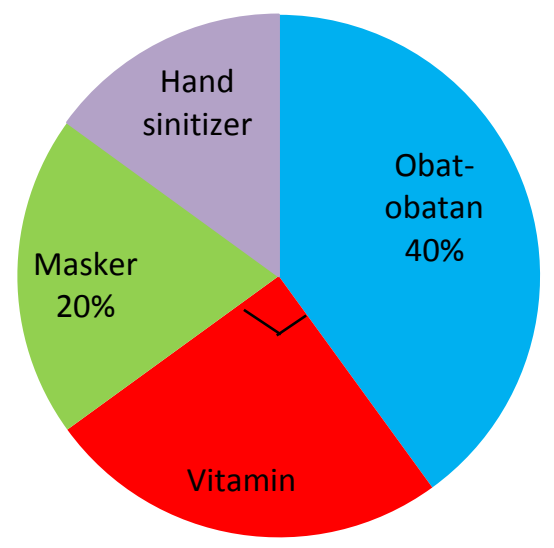

3 Perhatikan tabel kecepatan sepeda motor yang melaju dari SMP Negeri 11 Kota Bengkulu ke Pasar Kaget selama 10 menit.

Alifmatika: Jurnal Pendidikan dan Pembelajaran Matematika, Desember 2020, Vol. 2, No. 2 
Pengembangan Soal Statistika untuk Meningkatkan Kemampuan

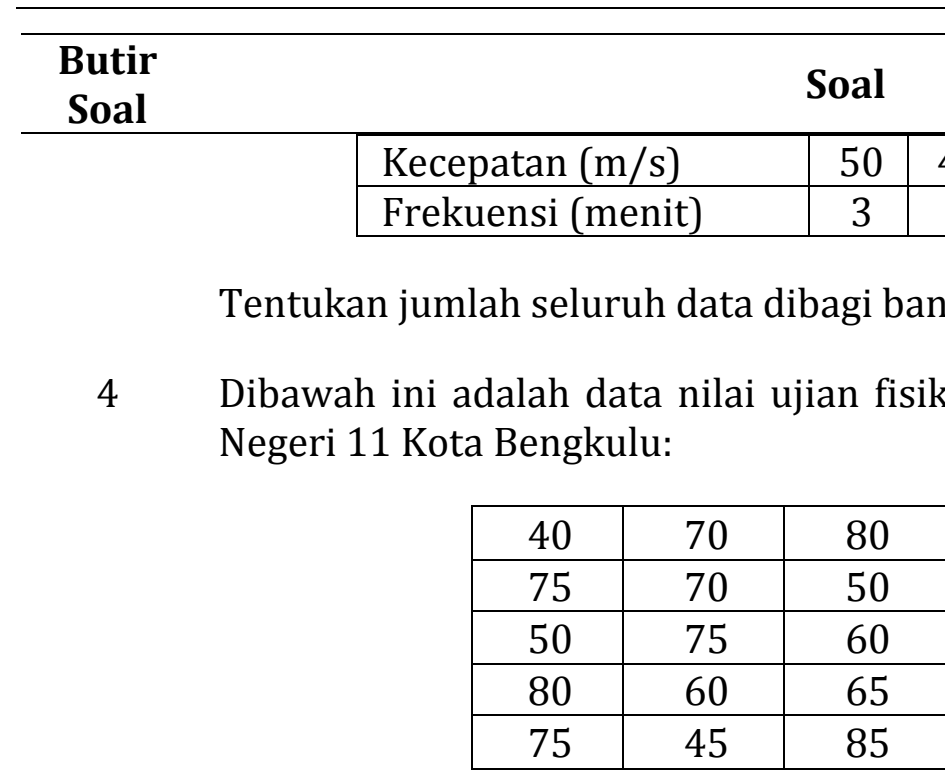

Jika KKM kelulusan adalah 75, berapakah persentase siswa yang tidak mengikuti remedial? dan tentukan rata-rata data di atas?

5 Tabel berikut menunjukkan penjualan hand sanitizer (barang) di apotek Ceria selama seminggu.

\begin{tabular}{|c|c|c|c|c|c|c|}
\hline Senin & Selasa & Rabu & Kamis & Jumat & Sabtu & Minggu \\
\hline 24 & 21 & 15 & 32 & 30 & 18 & 21 \\
\hline
\end{tabular}

Tentukan rata-rata penjualan hand sanitizer di apotek Ceria selama seminggu?

6 Data pertambahan pasien positif Covid-19 di Provinsi Bengkulu selama satu minggu sebagai berikut.

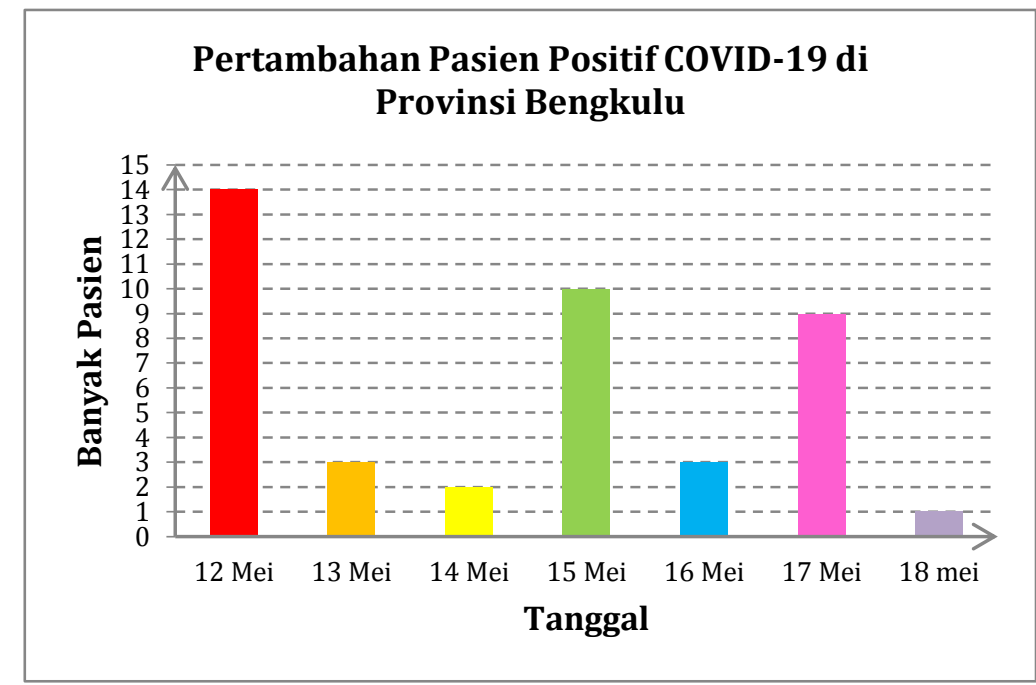

Tentukan rata-rata pertambahan pasien Covid -19 di Provinsi Bengkulu selama satu minggu?

Alifmatika: Jurnal Pendidikan dan Pembelajaran Matematika, Desember 2020, Vol. 2, No. 2 


\begin{tabular}{cl}
\hline $\begin{array}{c}\text { Butir } \\
\text { Soal }\end{array}$ & \multicolumn{1}{c}{ Soal } \\
\hline 7 & Apotek Bersama membeli masker Sensi sebanyak 5 box yang setiap box \\
& berisi 40 masker, dengan harga setiap box $R p .100 .000,-$ Jika apotek \\
& Bersama mendapat keuntungan sebanyak $R p . \quad 100.000,-$ Berapakah \\
& harga rata-rata masker perbuahnya?
\end{tabular}

8 Tabel di bawah ini menunjukkan data penjualan 15 nomor celana jeans di Toko Distro.

\begin{tabular}{|l|l|l|l|l|l|l|l|l|l|l|l|l|l|l|}
\hline \multicolumn{11}{|c|}{ Nomor Celana Jeans } \\
\hline 26 & 26 & 27 & 27 & 28 & 28 & 28 & 28 & 29 & 29 & 29 & 30 & 30 & 31 & 31 \\
\hline
\end{tabular}

Jika nomor celana yang laku terjual adalah nomor celana yang $\geq 28$. Berapa banyak celana jeans yang laku terjual? Jelaskan dan tentukan mean, nilai tengah dan nilai yang sering muncul pada data di atas?

$9 \quad$ Perhatikan tabel suhu udara di Kota Bengkulu 12 jam.

\begin{tabular}{|l|r|r|r|r|}
\hline Suhu $\left({ }^{\circ} \mathrm{C}\right)$ & 31 & 29 & 27 & 26 \\
\hline Frekuensi (jam) & 3 & 4 & 3 & 2 \\
\hline
\end{tabular}

Tentukan nilai tengah dan nilai yang sering muncul pada data tersebut?

10 Jika 6 orang siswi sedang mengambil nilai ujian praktek olahraga yaitu lari bolak-balik sejauh 5 meter dengan memindahkan 10 batu. Perhatikan grafik banyak batu yang dipindahkan 6 orang siswi dibawah ini:

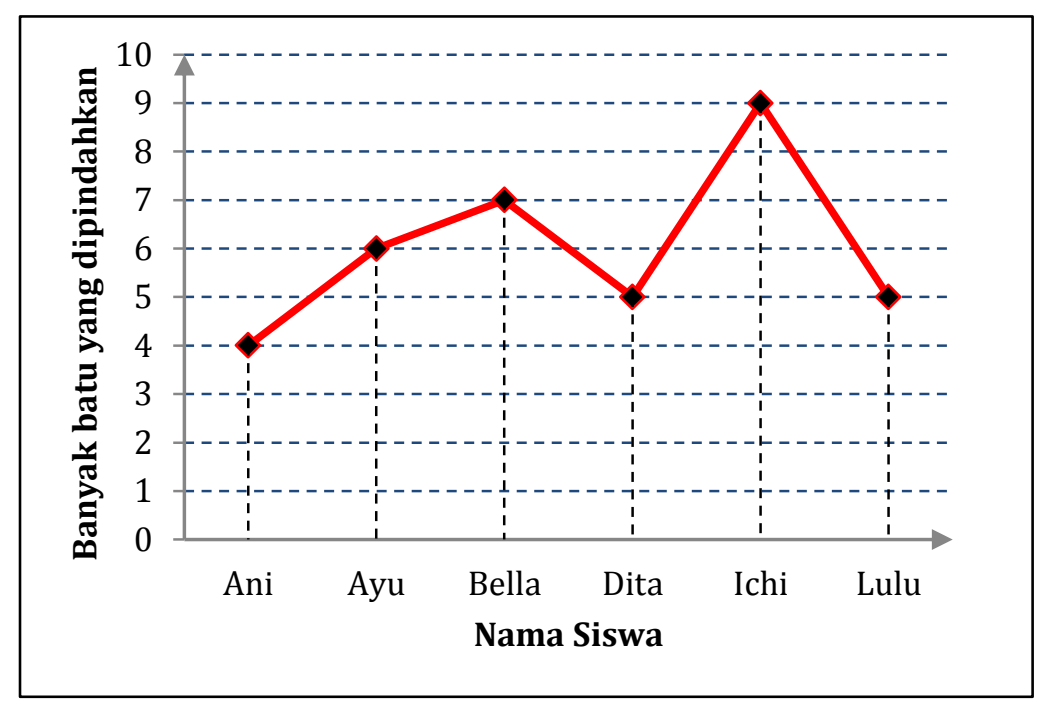

zukan median dan modus data di atas?

Alifmatika: Jurnal Pendidikan dan Pembelajaran Matematika, Desember 2020, Vol. 2, No. 2 
Pengembangan Soal Statistika untuk Meningkatkan Kemampuan

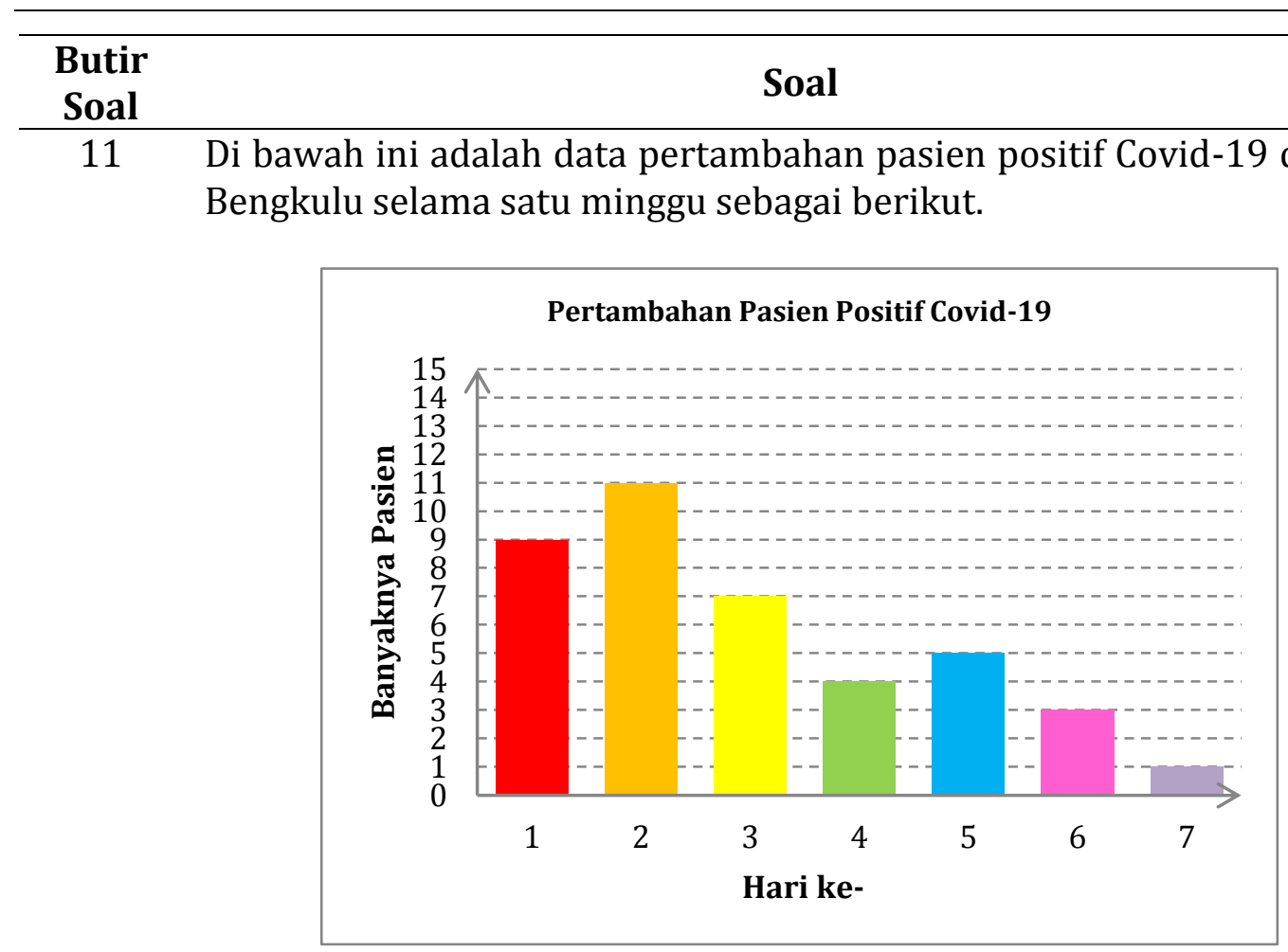

Tentukan selisih data terbesar dan data terkecil, serta tentukan seperempat data pertama dan seperempat data ke-empat?

12 Bella sedang mengerjakan tugas proyek biologinya yaitu mendata panjang kecambah kacang merah dalam kondisi lingkungan gelap selama satu minggu. Perhatikan grafik dibawah ini.

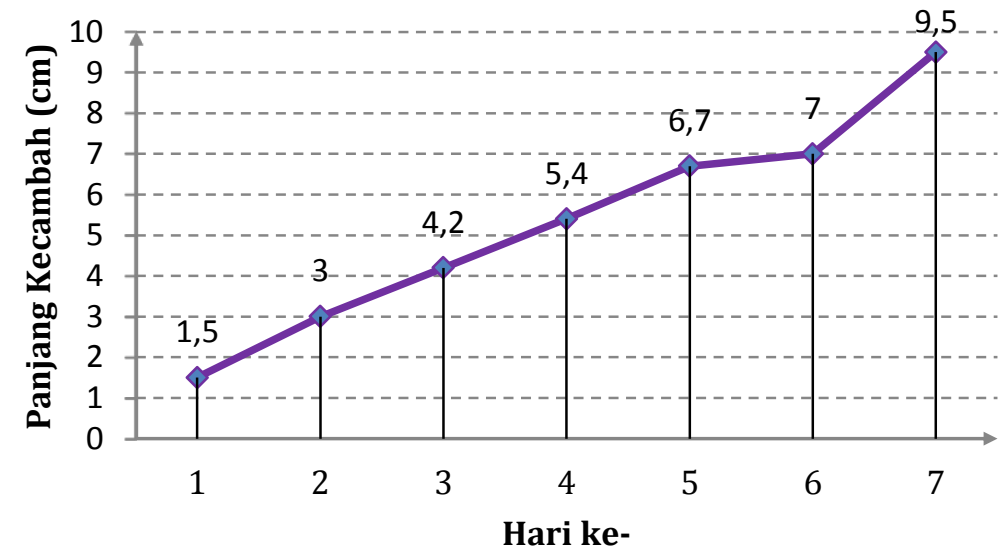

Tentukan selisih kuartil atas dan kuartil bawah data di atas? 


\begin{tabular}{|c|c|c|c|c|c|}
\hline Butir & \multicolumn{5}{|c|}{ Soal } \\
\hline \multirow[t]{5}{*}{13} & \multirow{5}{*}{\begin{tabular}{lrr} 
Tabel di & \multicolumn{2}{r}{ samping } \\
menunjukkan $\quad$ usia & para \\
kontestan & lomba & lari \\
marathon. Tentukan & kuartil \\
tengah, jangkauan & dan \\
jangkauan interkuartil & dari \\
usia kontestan tersebut? &
\end{tabular}} & \multicolumn{4}{|c|}{ Usia Para Kontestan } \\
\hline & & 20 & 23 & 30 & 20 \\
\hline & & 21 & 25 & 24 & 21 \\
\hline & & 22 & 23 & 26 & 27 \\
\hline & & 30 & 20 & 33 & 28 \\
\hline
\end{tabular}

14 Pak Oscar memanen buah rambutan milik kebunnya, dengan rata-rata hasil panen dari tahun 2015 sampai 2019 adalah 362 kg. Tentukan nilai $x$ dan hitunglah kuartil bawah dan kuartil atas?

\begin{tabular}{|c|c|c|c|c|c|}
\hline Tahun & 2015 & 2016 & 2017 & 2018 & 2019 \\
\hline Jumlah & 330 & 354 & $x$ & 432 & 470 \\
\hline
\end{tabular}

\section{KESIMPULAN DAN SARAN}

Penelitian ini menghasilkan produk soal essay untuk kemampuan koneksi matematis siswa pada materi Statistika. Berdasarkan hasil penelitian yang telah dilakukan dapat disimpulkan bahwa prototype soal yang dihasilkan telah valid dan praktis (terbaca). Menghasilkan butir soal matematika yang valid untuk kemampuan koneksi matematis sebanyak 14 soal. Valid tergambar dari hasil penilaian oleh pakar berdasarkan materi, konstruksi dan bahasa. Menghasilkan butir soal matematika yang praktis (terbaca) untuk kemampuan koneksi matematis sebanyak 14 soal. Praktis tergambar dari angket siswa dan komentar siswa secara kualitatif dan kuantitatif, serta sebagian siswa memahami soal yang sesuai dengan alur pikiran siswa. Kepraktisan (terbaca) pada soal nomor 1 hingga 14 berada pada interval $4 \leq R P_{\text {produk }} \leq 5$ yang tergolong sangat praktis.

Berdasarkan penelitian yang telah dilakukan, maka disarankan sebagai berikut: (1) pengembangan soal diharapkan dapat membantu siswa membiasakan diri menyelesaikan soal, dan meningkatkan kemampuan koneksi matematis siswa kelas VIII, (2) diharapkan dapat melanjutkan penelitian pengembangan soal essay untuk kemampuan koneksi matematis siswa kelas VIII ini ke tahap selanjutnya yaitu small group yang lebih luas bahkan hingga tahap field test.

\section{DAFTAR PUSTAKA}

Anggraena, Y. (2019). Pengembangan Kurikulum Matematika untuk Meningkatkan Kemampuan Siswa dalam Penalaran dan Pemecahan Masalah. Alifmatika: Jurnal Pendidikan Dan Pembelajaran Matematika, 1(1), 16-27. https://doi.org/10.35316/alifmatika.2019.v1i1.15-27

Arikunto, Suharsimi. (2018). Dasar-Dasar Evaluasi Pendidikan Evaluasi Pendidikan Edisi 3. Jakarta: Bumi Aksara. 
Arikunto, Suharsini. (2008). Dasar-dasar evaluasi pendidikan. Jakarta: Bumi Aksara.

As'ari, A. R., Tohir, M., Valentino, E., Imron, Z., \& Taufiq, I. (2017). Buku Guru Matematika (Revisi). Jakarta: Pusat Kurikulum Dan Perbukuan, Balitbang, Kemendikbud.

As'ari, A. R., Tohir, M., Valentino, E., Imron, Z., Taufiq, I., Hariarti, N. S., \& Lukmana, D. A. (2017). Matematika SMP/MTs kelas VIII semester 2. Jakarta: Pusat Kurikulum Dan Perbukuan, Balitbang, Kemendikbud.

Hodiyanto, H. (2017). Kemampuan Komunikasi Matematis Dalam Pembelajaran Matematika. AdMathEdu, 7(1), 9-18.

Kemendikbud. (2013). Peraturan Menteri Pendidikan Nasional Pendidikan Republik Indonesia No 64 Tahun 2013 tentang standar isi untuk tingkat satuan pendidikan dasar dan menengah. Retrieved from Jakarta: Kemendikbud website: https://luk.staff.ugm.ac.id/atur/bsnp/Permendikbud64-2013StandarIsi.pdf

Munawwarah, M., Laili, N., \& Tohir, M. (2020). Keterampilan Berpikir Kritis Mahasiswa dalam Memecahkan Masalah Matematika Berdasarkan Keterampilan Abad 21. Alifmatika: Jurnal Pendidikan Dan Pembelajaran Matematika, 2(1), 37-58. https://doi.org/10.35316/alifmatika.2020.v2i1.3758

NCTM. (2000). Principles and Standards for School Mathematics. United States of America: The National Council of Teacher of Mathematics, Inc. Retrieved from National Council of Teachers of Mathematics website: https://www.nctm.org/uploadedFiles/Standards_and_Positions/PSSM_Execu tiveSummary.pdf

Nopriyanti, T. D. (2015). Pengembangan Soal Matematika Untuk Mengukur Kemampuan Koneksi Matematis Siswa. Jurnal Dosen Universitas PGRI Palembang, 1(1), 1014-1028.

Permendikbud. (2014). Peraturan Menteri Pendidikan dan Kebudayaan Republik Indonesia No. 58 Tahun 2014 tentang Kurikulum Sekolah Menengah Pertama/ Madrasah Tsanawiyah. Retrieved from Jakarta: Kemendikbud website: https://jdih.kemdikbud.go.id/arsip/Permendikbud Nomor 58 Tahun 2014-digabungkan.pdf

Riwayati, S., \& Ridzky, K. (2020). Pengembangan Bahan Ajar Materi Segitiga Melalui PMRI di Sekolah Menengah Pertama. Jurnal MATH-UMB. EDU, 7(2).

Sugiyono. (2012). Statistik Non Parametris untuk Penelitian. Bandung: Alfabeta.

Ulpah, M. (2009). Belajar Statistika: Mengapa dan Bagaimana? INSANIA: Jurnal Pemikiran Alternatif Kependidikan, 14(3), 325-435.

Yusuf, A. M. (2017). Asesmen dan evaluasi pendidikan. Jakarta: Prenada Media.

Zulkardi. (2006). Formative Evaluation: what, why, when and how. Retrieved from Oocities website: http://www.oocities.org/zulkardi/books.html 